\title{
Prevalence and molecular characterization of Clostridium difficile isolated from European Barn Swallows (Hirundo rustica) during migration
}

\author{
Petra Bandelj ${ }^{1}$, Tomi Trilar ${ }^{2}$, Rok Blagus ${ }^{3}$, Matjaz Ocepek ${ }^{1}$, Joyce Rousseau ${ }^{4}$, J Scott Weese ${ }^{4}$ and Modest Vengust ${ }^{{ }^{*}}$
}

\begin{abstract}
Background: Clostridium difficile is an important bacterial pathogen of humans and a variety of animal species. Birds, especially migratory passerine species, can play a role in the spread of many pathogens, including Clostridium difficile. Barn Swallows (Hirundo rustica) nest in close proximity to human habitats and their biology is closely associated with cattle farming. Therefore, we hypothesized that Barn Swallows can be the reservoir of Clostridium difficile.

Results: Barn Swallows $(n=175)$ were captured on their autumn migration across Europe to sub-Saharan Africa. Droppings were collected from juvenile $(n=152)$ and adult birds $(n=23)$. Overall prevalence of Clostridium difficile was 4\% (7/175); 4.6\% (7/152) in juvenile birds and 0/23 in adults. Clostridium difficile ribotypes 078, 002 and 014 were identified, which are commonly found in farm animals and humans. Three new Clostridium difficile ribotypes were also identified: SB3, SB159 and SB166, one of which was toxigenic, harbouring genes for toxins A and B.

Conclusions: Results of this study indicate that Barn Swallows might play a role in national and international dissemination of Clostridium difficile and could serve as a source for human and animal infection. Clostridium difficile ribotype 078 was identified, which has been reported as an emerging cause of community-associated Clostridium difficile infection in humans. Based on this and other studies, however, it is more likely that Barn Swallows have a more indicative than perpetuating role in Clostridium difficile epidemiology.
\end{abstract}

Keywords: Clostridium difficile infection, Zoonosis, Migrating passerines, Birds, Cattle farming

\section{Background}

Clostridium difficile $(\mathrm{CD})$ is present in almost all human environments and is a potential zoonotic pathogen that can be isolated from a variety of animal species [1-5]. It is the most commonly diagnosed cause of antimicrobialand hospital-associated diarrhoea [6] and is an emerging cause of community-associated disease $[7,8]$. The presence of $\mathrm{CD}$ in animals, including those that come in close contact with humans as pets or through the food chain $[1,9]$, and the significant overlap between the types of $C D$ isolated from humans and animals [10-12], has lead to suggestion that $\mathrm{CD}$ might be a zoonotic and foodborne pathogen $[9,12]$.

Recognition of different potential sources of CD transmission remains a pressing clinical and investigative quest.

\footnotetext{
* Correspondence: modest.vengust@vf.uni-lj.si

'Veterinary faculty, University of Ljubljana, Ljubljana SI-1115, Slovenia

Full list of author information is available at the end of the article
}

Migratory birds travel between continents twice each year and are responsible for the transmission of several pathogens [13] and/or disease vectors [14]. The world's largest bird migration system is the Palaearctic-African flyway, which involves an estimated 2 billion passerines and nearpasserines migrating between the European continent and sub-Saharan Africa [15].

An epidemiological study on mostly migrating passerine birds in Europe suggested that they are unlikely to serve as a carrier or reservoir of CD [16]. However, the study [16] was conducted in the region where Barn Swallows (Hirundo rustica) were not congregating during their migration south, and included only garden birds unlikely to dwell in habitats intensively cultivated by humans. On the other hand, Barn Swallows, come in close contact with human habitats $[17,18]$, as do House Sparrows (Passer domesticus), which are a non-migrating passerine bird, that have been associated with $\mathrm{CD}$ when sampled on pig farms [19]. 
Barn Swallows are among most common and widespread migratory birds in the Palaearctic. In Europe they most commonly nest in cattle farms inside the barns or stables, which had a significant evolutionary effect on Barn Swallow biology with regards to their nesting habits. Any changes in their environment significantly affect their population $[17,18]$. Its habit of nesting in buildings associated with human habitation has made this species one of the most familiar bird species in the world [20] as well as a potential source for international and local CD perpetuation. The aims of the present study were to determine the prevalence of CD in Barn Swallows, and to characterize $\mathrm{CD}$ isolates.

\section{Methods}

Sampling of Barn Swallows was conducted once in September 2011 in the central part of Slovenia $\left(46^{\circ} 0^{\prime}\right.$ $2.12^{\prime \prime} \mathrm{N}, 14^{\circ} 22^{\prime} 58.27^{\prime \prime} \mathrm{E}$ ) in an area identified as a Barn Swallow congregation point during their autumn migration across Europe (average week temperature $21.8^{\circ} \mathrm{C}$, average week humidity $69.5 \%$ ). One hundred seventy-five $(\mathrm{n}=175)$ Barn Swallows were captured with mist nets and placed individually in clean custom made hot pressed plastic containers with air holes. Bird faeces, if present, were collected from containers using sterile gloves (Ansell Ltd, UK) after the birds were removed for standard general inspection, ringing and release to continue with their migration. Faeces were transferred into $2 \mathrm{~mL}$ sterile tubes (Eppendorf Tubes, Germany) and stored at $-20^{\circ} \mathrm{C}$ until analysed for the presence of $\mathrm{CD}$ spores.

The study was carried out with animal ethics approval by the Ministry of the Environment and Spatial Planning (document No.: 35601-10/2010-6).

\section{Clostridium difficile culture}

Entire samples were inoculated into $9 \mathrm{~mL}$ of $\mathrm{CD}$ moxalactam norfloxacin (CDMN) enrichment broth (Oxoid Ltd; Nepean, ON Canada) containing $0.1 \%$ sodium taurocholate. Anaerobic incubation at $37^{\circ} \mathrm{C}$ lasted for 7 days. An aliquot of broth was transferred to a new vial and an equal amount of anhydrous alcohol was added to each sample. This was followed by a $60 \mathrm{~min}$ incubation at room temperature, centrifugation $(3800 \mathrm{~g}$ for $10 \mathrm{~min}$ ) and inoculation of the pellets onto CDMN (Oxoid Ltd; Nepean, ON Canada) agar. Further incubation in an anaerobic chamber for 2 days at $37^{\circ} \mathrm{C}$ was followed by another 3 days if necessary. Isolation and identification of $\mathrm{CD}$ was based on the characteristic morphology and odour of the colonies, Gram stain and the presence of the L-proline aminopeptidase activity (Remel Inc, Lenexa, KS, USA). One single colony for each isolate was subcultured and stored at $-80^{\circ} \mathrm{C}$ and re-cultured prior to molecular analysis.

\section{Molecular analysis}

Extraction of DNA was done on pure cultures after they were obtained from blood agar with a Chelex resin-based DNA extraction commercial kit (InstaGene Matrix, Bio-Rad Laboratories, USA), following the manufacturer's instructions. Extracted DNA was used as template for further molecular analysis. Ribotyping was performed as previously described by [21]. Ribotpyes were assigned visually based on comparison with an internal library of ribotypes as well as reference strains from the Cardiff ECDC reference library. Testing for genes encoding toxins A $(t c d A)$ and B $(t c d B)$ was performed by PCR as previously described by [22]. The presence of the gene encoding the binding component of the binary toxin $(c d t A)$ was detected as described in [23].

\section{Results}

A total of 175 samples were taken from 152 juvenile and 23 adult Barn Swallows. Seven $(7 / 175 ; 4 \%)$ samples were positive for $\mathrm{CD} ; 7 / 152$ (4.61\%) juveniles and $0 / 23$ adults. Five $(5 / 7 ; 71 \%)$ isolates were toxigenic. All five toxigenic isolates possessed $t c d A$ and $t c d B$ while two also possessed $c d t A$. Clostridium difficile isolates that were toxin $\mathrm{A}, \mathrm{B}$ and CDT (Clostridium difficile toxin/binary toxin) positive, were identified as ribotype 078. Single isolates of ribotypes 002 and 014 were also identified. The remaining three ribotypes, one of which was toxigenic, had not been previously identified in this laboratory or documented in the available Cardiff ECDC collection (Table 1).

\section{Discussion}

This is the first study investigating Barn Swallow as a possible source of $\mathrm{CD}$ for farm animals and humans. In the past, there has been increasing concern about animals as potential CD reservoirs and sources of human exposure [12,24]. Of particular note is the finding of ribotype 078. This strain is common in food animals $[4,25,26]$ and has been reported as an emerging and increasing cause of community-associated Clostridium difficile infection (CDI) in humans [25,27,28]. Two of the

Table 1 Clostridium difficile toxins and ribotypes in Barn Swallows (Hirundo rustica)

\begin{tabular}{cc}
\hline \multicolumn{2}{c}{ Clostridium difficile } \\
\hline Toxins & Ribotype \\
\hline $\mathrm{A}+\mathrm{B}+\mathrm{CDT}+$ & 078 \\
$\mathrm{~A}+\mathrm{B}+\mathrm{CDT}-$ & 002 \\
$\mathrm{~A}+\mathrm{B}+\mathrm{CDT}-$ & 014 \\
$\mathrm{~A}+\mathrm{B}+\mathrm{CDT}-$ & $\mathrm{SB} 166^{*}$ \\
$\mathrm{~A}-\mathrm{B}-\mathrm{CDT}-$ & $\mathrm{SB} 3^{*}$ \\
A-B-CDT- & $\mathrm{SB} 159^{*}$ \\
\hline
\end{tabular}

*Newly identified ribotypes. 
three other toxigenic ribotypes identified in this study (002, 014) can be found both in humans and animals [26,29]. Three new CD ribotypes were also identified (SB3, SB159, SB166), one possessing A + B + CDT- (SB166).

It was interesting that $\mathrm{CD}$ was only found in juvenile birds. The sample population in this study was predominantly juvenile birds, which is in concordance with the expected ratio of juvenile birds on migration $(>80 \%)$ $[16,30]$. In most studied animal species, CD tends to predominate in younger animals [31,32]. There is no evidence that $\mathrm{CD}$ causes disease in Barn Swallows.

Currently, the epidemiology of community-associated CDI is poorly understood. Food animals and food have been suggested as sources of human exposure [9,33]; however, other potential forms of exposure in the community must be considered. While the high prevalence of $\mathrm{CD}$ in some farm animal groups clearly indicates that they could be reservoirs of $\mathrm{CD}$, the potential for other animals to act as a source of $\mathrm{CD}$ from farms to the broader human or animal population is intriguing. The biology of Barn Swallows potentially makes them a very efficient vector for CD dissemination. They are the most common and widespread migratory bird in Europe and cohabit with farm animals and humans $[17,18,20]$.

Passerine birds were previously not determined to be the source of $\mathrm{CD}$; however, only passerines unlikely to come in close contact with humans have been investigated [16]. In contrary, House Sparrows, a non-migrating passerine, had previously been associated with $\mathrm{CD}$ on pig farms in the Netherlands [19]. European Barn Swallows, the species studied here, preferably nest within the cattle barns during warm months of the year, and spend the winter in Sub-Saharan Africa. Some can migrate to Arabia and to the Indian sub-continent $[17,18]$. In our study, a total of $4 \%$ of all captured and sampled Barn Swallows were positive for $\mathrm{CD}$, which reflects the prevalence of adult cattle in some reports. Given the presence of $\mathrm{CD}$ in the bovine population, with reported prevalence of $2.4-6.3 \%$ in adult cattle and $7.6-51 \%$ in calves [3,5,34] and the nesting locations of Barn Swallows, it is certainly plausible that these birds could acquire $\mathrm{CD}$ on farms. Interestingly, to date, including this study, $C D$ was isolated only from wild birds that are associated with intensively farmed habitats $[16,19]$. Therefore, it is more likely that Barn Swallows have a more indicative than perpetuating role in $\mathrm{CD}$ epidemiology.

\section{Conclusions}

Results of this study showed that Barn Swallows could potentially be a source of $\mathrm{CD}$ in humans and animals. During their congregation at migration destinations interindividual and interspecies horizontal transmission can occur [13]. However, based on this and previous studies on the prevalence of $C D$ in wild passerine birds $[16,19]$, and studies associated with farm animals and humans $[10,27,31,32,35]$, Barn Swallows may more realistically be an indicator and not the source of the contamination of $\mathrm{CD}$ in the environment. It seems that intensive farming and hospital environment are the sources of CD, and only humans and/or animals associated with such environment perpetuate $\mathrm{CD}$.

\section{Abbreviations \\ CD: Clostridium difficile; CDI: Clostridium difficile infection.}

\section{Competing interests}

Authors have no competing interests to declare.

\section{Authors' contributions}

All of the authors contributed to the conception design, interpretation of data, drafting the article and critical revision of the manuscript. PB, $T T$ and MV collected samples from Barn Swallows. JSW and JR performed bacterial culture and molecular analysis. All authors approved the final version of this manuscript.

\section{Acknowledgement}

Authors would like to acknowledge the assistance of Dr. Katarina Prosenc Trilar, Dr. Anton Vengust, Matej Loncar, Katjusa Vengust for their assistance during collection of samples for this study. The assistance of Uros Jarc, Panplast, Logatec, Slovenia, was greatly appreciated. This study was supported by the Slovenian Research Agency grant P4-0053 and P4-0092.

\section{Author details}

${ }^{1}$ Veterinary faculty, University of Ljubljana, Ljubljana SI-1115, Slovenia. ${ }^{2}$ Slovenian Museum of Natural History, Ljubljana SI-1000, Slovenia. ${ }^{3}$ Institute for Biostatistics and Medical Informatics, University of Ljubljana, Ljubljana SI-1 104, Slovenia. ${ }^{4}$ Department of Pathobiology, Ontario Veterinary College, University of Guelph, Guelph, Ontario N1G 2W1, Canada.

Received: 25 September 2013 Accepted: 6 February 2014

Published: 8 February 2014

\section{References}

1. Borriello SP, Honour P, Turner T, Barclay F: Household pets as a potential reservoir for Clostridium difficile infection. J Clin Pathol 1983, 36(1):84-87.

2. Weese JS, Staempfli HR, Prescott JF: A prospective study of the roles of Clostridium difficile and enterotoxigenic Clostridium perfringens in equine diarrhoea. Equine Vet J 2001, 33(4):403-409.

3. Rodriguez-Palacios A, Staempfli HR, Duffield T, Peregrine AS, Trotz-Williams LA, Arroyo LG, Brazier JS, Weese JS: Clostridium difficile PCR ribotypes in calves, Canada. Emerg Infect Dis 2006, 12(11):1730-1736.

4. Keel K, Brazier JS, Post KW, Weese JS, Songer JG: Prevalence of PCR ribotypes among Clostridium difficile isolates from pigs, calves, and other species. J Clin Microbiol 2007, 45(6):1963-1964.

5. Avbersek J, Janezic S, Pate M, Rupnik M, Zidaric V, Logar K, Vengust M, Zemljic M, Pirs T, Ocepek M: Diversity of Clostridium difficile in pigs and other animals in Slovenia. Anaerobe 2009, 15(6):252-255.

6. Poutanen S, Simor A: Clostridium difficile-associated diarrhea in adults. CMAJ 2004, 171(1):51-58.

7. Limbago BM, Long CM, Thompson AD, Killgore GE, Hannett GE, Havill NL, Mickelson S, Lathrop S, Jones TF, Park MM, Harriman KH, Gould LH, McDonald LC, Angulo FJ: Clostridium difficile strains from communityassociated infections. J Clin Microbiol 2009, 47(9):3004-3007.

8. Juneau C, Mendias EN, Wagal N, Loeffelholz M, Savidge T, Croisant S, Dann S: Community-acquired Clostridium difficile infection: Awareness and clinical implications. J Nurse Pract 2013, 9(1):1-6.

9. Weese JS: Clostridium difficile in food-innocent bystander or serious threat? Clin Microbiol Infect 2010, 16(1):3-10.

10. Arroyo LG, Kruth SA, Willey BM, Staempfli HR, Low DE, Weese JS: PCR ribotyping of Clostridium difficile isolates originating from human and animal sources. J Med Microbiol 2005, 54(pt 2):163-166.

11. Rodriguez-Palacios A, Staempfli HR, Duffield T, Weese JS: Clostridium difficile in retail ground meat, Canada. Emerg Infect Dis 2007, 13(3):485-487. 
12. Rupnik M: Is Clostridium difficile-associated infection a potentially zoonotic and foodborne disease? Clin Microbiol Infect 2007, 13(5):457-459.

13. Hubálek Z: An annotated checklist of pathogenic microorganisms associated with migratory birds. J Wildl Dis 2004, 40(4):639-659.

14. Comstedt P, Bergström S, Olsen B, Garpmo U, Marjavaara L, Mejlon H, Barbour AG, Bunikis J: Migratory passerine birds as reservoirs of lyme boreliosis in Europe. Emerg Infect Dis 2006, 12(7):1087-1095.

15. Hahn S, Bauer S, Liechti F: The natural link between Europe and Africa - 2.1 billion birds on migration. Oikos 2009, 118(4):624-626.

16. Bandelj P, Trilar T, Racnik J, Zadravec M, Pirš T, Avbersek J, Micunovic J, Ocepek M, Vengust M: Zero prevalence of Clostridium difficile in wild passerine birds in Europe. FEMS Microbiol Lett 2011, 321(2):183-185.

17. Cramp S: The birds of western palaearctic, Volume V. Oxford, UK: Oxford University Press; 1998.

18. Møller AP: The effect of dairy farming on Barn swallow Hirundo rustica abundance, distribution and reproduction. J Appl Ecol 2001, 38(2):378-389.

19. Burt SA, Siemeling L, Kuijper EJ, Lipman LJ: Vermin on pig farms are vectors for Clostridium difficile PCR ribotypes 078 and 045 . Vet Microbiol 2012, 160(1-2):256-258.

20. Brown CR, Bomberger Brown M: Barn swallow (Hirundo rustica). In The Birds of North America Online. Edited by Poole A, Ithaca: Cornell Lab of Ornithology, 1999. http://bna.birds.cornell.edu/bna/species/452/articles/ introduction (2013-08-22).

21. Bidet P, Barbut F, Lalande V, Burghoffer B, Petit JC: Development of a new PCR-ribotyping method for Clostridium difficile based on ribosomal RNA gene sequencing. FEMS Microbiol Lett 1999, 175(2):261-266.

22. Kato $H$, Kato N, Watanabe $K$, Iwai N, Nakamura $H$, Yamamoto T, Suzuki $K$, Kim SM, Chong Y, Wasito EB: Identification of toxin A-negative, toxin B-positive Clostridium difficile by PCR. J Clin Microbiol 1998, 36(8):2178-2182.

23. Stubbs S, Rupnik M, Gibert M, Brazier J, Duerden B, Popoff M: Production of actin-specific ADP-ribosyltransferase (binary toxin) by strains of Clostridium difficile. FEMS Microbiol Lett 2000, 186(2):307-312.

24. Hensgens MP, Keessen EC, Squire MM, Riley TV, Koene MG, de Boer E, Lipman $\amalg$, Kuijper EJ, European Society of Clinical Microbiology and Infectious Diseases Study Group for Clostridium difficile (ESGCD): Clostridium difficile infection in the community: a zoonotic disease? Clin Microbiol Infect 2012, 18(7):635-645.

25. Rupnik M, Widmer A, Zimmermann O, Eckert C, Barbut F: Clostridium difficile toxinotype $\mathrm{V}$, ribotype 078 , in animals and humans. J Clin Microbiol 2008, 46(6):2146.

26. Janezic S, Ocepek M, Zidaric V, Rupnik M: Clostridium difficile genotypes other than ribotype 078 that are prevalent among human, animal and environmental isolates. BMC Microbiol 2012, 12:48.

27. Goorhuis A, Debast SB, van Leengoed LA, Harmanus C, Notermans DW, Bergwerff AA, Kuijper EJ: Clostridium difficile PCR ribotype 078: an emerging strain in humans and in pigs? J Clin Microbiol 2008, 46(3):1157.

28. Bakker D, Corver J, Harmanus C, Goorhuis A, Keessen EC, Fawley WN, Wilcox MH, Kuijper EJ: Relatedness of human and animal Clostridium difficile PCR ribotype 078 isolates determined on the basis of multilocus variable-number tandem-repeat analysis and tetracycline resistance. $J$ Clin Microbiol 2010, 48(10):3744-3749.

29. Vanek J, Hill K, Collins J, Berrington A, Perry J, Inns T, Gorton R, Magee J, Sails A, Mullan A, Gould FK: Epidemiological survey of Clostridium difficile ribotypes in the North East of England during an 18-month period. J Hosp Infect 2012, 81(3):209-212.

30. Jakubas $D$, Wojczulanis-Jakubas $K$ : Sex- and age-related differences in the timing and body condition of migrating Reed Warblers Acrocephalus scirpaceus and Sedge Warblers Acrocephalus schoenobaenus. Naturwissenschaften 2010, 97(5):505-511.

31. Zidaric V, Zemljic M, Janezic $S$, Kocuvan A, Rupnik M: High diversity of Clostridium difficile genotypes isolated from a single poultry farm producing replacement laying hens. Anaerobe 2008, 14(6):325-327.

32. Alvarez-Perez S, Blanco JL, Bouza E, Alba P, Gibert X, Maldonado J, Garcia ME: Prevalence of Clostridium difficile in diarrhoeic and non-diarrhoeic piglets. Vet Microbiol 2009, 137(3-4):302-305.

33. Freeman J, Bauer MP, Baines SD, Corver J, Fawley WN, Goorhuis B, Kuijper EJ, Wilcox MH: The changing epidemiology of Clostridium difficile infections. Clin Microbiol Rev 2010, 23(3):529-549.
34. Thitaram SN, Frank JF, Lyon SA, Siragusa GR, Bailey JS, Lombard JE, Haley CA, Wagner BA, Dargatz DA, Fedorka-Cray PJ: Clostridium difficile from healthy food animals: optimized isolation and prevalence. J Food Prot 2011, 74(1):130-133.

35. Weese JS, Reid-Smith RJ, Avery BP, Rousseau J: Detection and characterization of Clostridium difficile in retail chicken. Lett Appl Microbiol 2010, 50(4):362-365.

doi:10.1186/1746-6148-10-40

Cite this article as: Bandelj et al.: Prevalence and molecular characterization of Clostridium difficile isolated from European Barn Swallows (Hirundo rustica) during migration. BMC Veterinary Research 2014 10:40

\section{Submit your next manuscript to BioMed Central and take full advantage of:}

- Convenient online submission

- Thorough peer review

- No space constraints or color figure charges

- Immediate publication on acceptance

- Inclusion in PubMed, CAS, Scopus and Google Scholar

- Research which is freely available for redistribution 